\title{
The Harmonization of Spiritual and Intellectual Intelligence in Education for Gifted Children Based on Islamic Theological Perspective
}

\author{
$1^{\text {st }}$ Kemil Wachidah \\ Universitas Muhammadiyah Sidoarjo \\ Jl. Mojopahit 666B, Sidoarjo \\ Indonesia \\ kemilwachidah@umsida.ac.id \\ $4^{\text {th }}$ Niko Fediyanto \\ Universitas Muhammadiyah Sidoarjo \\ Jl. Mojopahit 666B, Sidoarjo \\ Indonesia
}

\author{
$2^{\text {nd }}$ Udin Syaefudin Sa'ud \\ Universitas Pendidikan Indonesia \\ Bandung, Indonesia
}

$5^{\text {th }}$ Joko Susilo

Universitas Muhammadiyah Sidoarjo

Jl. Mojopahit 666B, Sidoarjo

Indonesia

\author{
$3^{\text {rd }}$ Dian Novita \\ Universitas Muhammadiyah Sidoarjo \\ Jl. Mojopahit 666B, Sidoarjo \\ Indonesia
}

\begin{abstract}
The cultural-specific characteristics of western societies create obstacles to the inclusion of spirituality in gifted individual conceptions. One of the greatest cultural ideas in Western society is the relationship between religion and science, which is parallel to the relationship between talent and spirituality in education for the gifted. Western societies are disturbed by stereotypes with regard to spirituality and talent so the method of reviewing the literature review is important for analyzing and applying elements from the broader views of Islamic philosophers. As offered by Al-Ghazali, curriculum development for gifted students embodies spiritual and intellectual harmonization. The results of the research study state that this research has examined various educational concepts postulated by Islamic thinkers in relation to gifted education. Although this perspective is somewhat different, Islam places the same emphasis on the importance of increasing knowledge, intelligence and intelligence, spirituality, emotions and morality.
\end{abstract}

Keywords—Spiritual intelligence, Gifted, Islamic Theology

\section{INTRODUCTION}

Over the past few decades, the concept of gifted education has received a great deal of consideration and review. In the late twentieth century, many researchers such as (Sapon-Shevin, 1995) and (Barlow, 2006), ), opposed the practice of gifted education programs, arguing that they were a means of reproducing social inequality. Recent reviews of gifted education have produced perceptions for developing higher-level thinking and analytical abilities of students with potential (Borland, 2005). Currently, governments around the world promote and support the design of special education programs for gifted children to develop their talents (Robinson, Shore \& Enersen, 2006).

From the earliest days of Islamic existence, consistent with the Platonic view of the nature of the divided world,
Muslim education has placed the study of the Qur'an and the teachings of Muhammad, along with Islamic dogma and ideology, on the main agenda. Al-Ghazali (1058 - 1111 $\mathrm{AD}$ ) is regarded as the father of Islamic education thought as Plato is regarded as a protector of Western educational thought. Al-Ghazali defines the main purpose of education is to assist someone in obtaining all aspects and dimensions of knowledge to achieve one's true happiness. (Batterjee, 2013).

Recognizing the value of knowledge in its use and reallife applications, Muslim researchers promote the formation of intelle Al-Ghazali considers happiness to be achieved only if knowledge ('ilm) is related to actions (' amal), whereas the meaning of action is to utilize the desires of the soul, control anger, control anger, and curb them. Man's manifestation of emotion by making it a reason. Therefore, it is not natural talent that distinguishes talented people from the non-talented, but rather the capacity to translate knowledge into action. Gifted Muslims are people who act on their knowledge.

The similarity with Plato with Al-Ghazali's beliefs is about the necessity of forming cognitive capital, and hence differentiating between the two types of school and education. In addition, al-Ghazali was known for sharing many ideas with Aristotle and Thomas Aquinas, because he shared the idea that a good educational setting provides a balance between human reason and the divine light of God. Nonetheless, in deviating from the emphasis found generally among the West inspired by the Greeks, AlGhazali considers all children to have the capacity to learn: "knowledge exists potentially in the human soul like seeds in the ground; by studying the potential to be actual "(in Tibawi, 1972, p. 40). In addition, Tibawi (1972) reports on Al-Ghazali's views on moral education as ensuring one's happiness in the human and spiritual world.ctual elites, but 
for reasons different from those promoted by Plato. As clarified by (Taylor, 2005).

The culture-specific characteristics of Western societies create obstacles to the inclusion of spirituality in gifted individual conceptions (Ubani, 2007). One of the greatest cultural ideas in Western society is the relationship between religion and science (Noddings, 1997). This relationship is parallel with the relationship between talent and spirituality in education for the gifted. Western society is disturbed by stereotypes regarding spirituality and talent. The belief that talented people are only those who excel in academic environments is one such stereotype. Gifted individuals are continually believed to score high on IQ tests (Reynolds \& Piirto, 2005). Therefore, even though spirituality is believed to be an important element of gifted education, it still finds its way to get into the school system.

Empirical studies also identify the need for teachers to have discussions about moral, spiritual, and religious questions that will have an impact on students' future. Questions about spirituality and religion are high among issues concerning adolescents, and such questions need to be answered in every culture so young people can clarify questions that make them understand themselves and their responsibilities better. Teenagers need answers to these questions so they can improve not only their cognitive dimensions, but also the moral and spiritual aspects of their lives. Talented students are concerned with such questions which are also included in moral education and citizenship (Tirri, 2007).

Recent developments in emotional neuroscience emphasize the relationship between cognitive and emotional functions that have the ability to change our perceptions of learning with regard to school. The relationship between decision making, social functioning and moral interpretation has many promises to bring a greater level of understanding of how emotions affect decision making. The relationship between learning and emotions, how learning is influenced by culture, and finally how human morals and ethics are developed, are the same component. Educators provide very important topics because their aim is to develop students who are skilled, knowledgeable and ethical who have the potential to face the social and moral challenges of their daily lives. (Immordino-Yang \& Damasio, 2007).

Therefore, it is important to analyze and apply elements of a broader view of Islamic philosophers, such as those offered by Al-Ghazali, to develop curriculum for gifted students in order to realize spiritual and intellectual harmonization.

\section{METHOD}

This research is a library research, which is a series of studies relating to library data collection methods (books, encyclopedias, scientific journals, newspapers, magazines, and documents). A literature review or literature research is a study that reviews or critically reviews knowledge, ideas, or findings contained in the body of academicoriented literature, and formulates theoretical and methodological contributions for a particular topic. The focus of library research is to find various theories, laws, propositions, principles, or ideas that are used to analyze and solve research questions that are formulated. The analysis is done descriptively, i.e. a regular breakdown of the data that has been obtained and then given an understanding and explanation so that it can be understood properly by the reader.

\section{A. Data Collecting Method}

In a library research, library data is processed by selecting, searching, presenting, and analyzing. The source of this research data is looking for library data whose substance requires philosophical and theoretical processing. Literature study in this research is a literature study without empirical tests. The data presented is data in the form of words that require processing to be concise and systematic. Data collection is done by collecting articles, research results, books on spiritual and intellectual concepts in the perspective of Islamic philosophers, such as Al Ghazali, Al Farabi. Then selected, presented and analyzed and processed to be concise and systematic.

\section{B. Data analysis technique}

In this study using data analysis techniques in the form of content analysis (content analysis). Content analysis is a scientific analyst about the contents of a data message. So, as an analytical and comparative material on al-Gazali's thinking about spiritual and intellectual intelligence is secondary data, so it can be seen the meaning, position and relationship of the two intelligences with the education of Gifted Children.

\section{FINDING AND DISCUSSION}

A. The Concepts of Mind and Intelligence in Education for The Gifted

Aristotle defines the human mind as "the part of the soul used by humans to know and understand" (Barnes, 2014). This idea is then used to develop the concept of knowledge, which underlines that an individual must use their minds to clarify and understand phenomena while strategizing on actions. This theory is clarified by Aristotle in De Anima, a work in which he distinguishes active and passive intelligence (Barnes, 2014). The latter means an innate capacity for certain intellectual awareness of the basic concepts and realities around them, while the former means an active knowledge-construction capacity that can be done only consciously and intentionally by individuals through education and self-development.

Previous intelligence has been presented as a concept that distinguishes individuals through their ability to understand complex ideas with the help of rational thought and reason (Barnes, 2014). Rational thinking requires training. Both ancient Greek and Islamic scholars stated that gifted individuals need extensive training to develop their rational thinking and improve their ability to understand (Cooper, 2012). However, the concept of intelligence is always discussed in the context of its relationship with the intellect, so researchers explore these two ideas as interconnected.

Research of Islamic thinkers related to intelligence and intelligence has focused on "Aql" (the Islamic word for 'intelligence') which is called the ability to use reasoning and give good judgment (Cholik, 2015). According to AlGhazali, Al-aql is a gift from God, which gives humans the opportunity to use their intelligence, foster their desire to 
learn and, ultimately, gain knowledge, knowledge. For talented people to reach science, there is a need for them to develop their intelligence and intelligence, and to apply it to their advantage (Fuadi, 2013). However, it is also important to remember that an understanding of Islamic attitudes towards intelligence and intelligence would not be complete without understanding its intimate relationship with God. As indicated by (Norsaleha Mohd. Salleh \& Noor Hafizah Mohd. Haridi, 2016), p Islamic thinkers have always linked intelligence with a connection to God, and Ibn Sina worked extensively in showing all stages of intellectual development experienced by people, and the Divine stage. Active intelligence that they can achieve through continuous self development. Therefore, the main and final goal of developing intelligence in the Islamic tradition is seen as one's binding with God and one's Origin, while intelligence is essentially a way to understand God's revelation.

Although ancient Western and Islamic scholars connected many of their perceptions of intelligence with divine gifts, Western thought began to regard the intellect and intelligence in almost purely scientific terms with the passage of time (especially after the Enlightenment which established the rules of rational science and thought in the scientific tradition). The development of IQ tests in the early twentieth century enabled researchers to measure intelligence, and the theory of biological inheritance from sophisticated intellectual abilities had had a large influence on academic thought in the West for quite a long period of time (Sternberg, 2000). These tests were introduced primarily to measure the ability to solve logical problems, which are believed to reflect intelligence and intelligence more than others. However, researchers soon realized that IQ tests only measure the limited scope of people's abilities, eliminating aspects of intelligence such as intrapersonal, spatial, musical, kinesthetic, mathematical, naturalistic, and linguistic (Sternberg, 2000). Therefore, Western research on the nature and criteria of intelligence develops largely due to the introduction of the Structure of Intellect model by (Carroll \& Guilford, 1968), research on the multidimensional structure of multidimensional talent presented by (Sternberg, 2000), and the development of (Gardner, 1995), in terms of multidimensional manifestations of intelligence through human performance.

This development is clearly a positive step forward in the reconciliation of intelligence because multidimensional concepts are not only reflected in convergent thinking as measured by IQ tests, but also in different forms of thinking such as creative problem solving, emotional intelligence, spirituality, leadership qualities, etc. Therefore, there is a spectrum of opinion that is far more heterogeneous about the nature and manifestations of intelligence in Western thought now compared to ancient science, the Middle Ages, and even modern 20th century. Interestingly, it can be observed that the convergence of Islamic and Western views on intelligence is now in terms of increasing recognition of the spiritual and emotional components by Western scholars, which were not present in the formal IQ testing approach a few decades ago. Islamic research on intelligence has traditionally included the spiritual dimension of intelligence which is directed at relationship with God and is driven by illumination through faith. Therefore, as can be seen, there are compelling reasons to integrate Islamic and Western research on intelligence in finding a combined approach to education for the gifted.

B. Education for Gifted in an Islamic Context

To study gifted from an Islamic perspective, it is important to observe the way Muslim scholars describe human nature and the various factors that influence it. Some Muslim scholars discuss aspects of human nature in different ways when trying to understand its complexity. Muslim intellectuals such as Abu Hamid Al-Ghazali (1058 - 1111), Jalaluddin Rumi (1207 - 1273), Ibn Khaldun (1332 - 1406), Shah Waliullah (1703 - 1762), Jamal-ad-Din AlAfghani (1838 - 1897) ) and Sayyid Qutb (1906 - 1966) emphasized the influence parents have and education on individual development. They emphasize the importance of raising children in the right way to ensure the inculcation of true values.

In the Islamic context, education refers to a process that takes into account all persons, including spiritual, rational and social aspects. The aim is to develop an integrated approach to teaching and develop a balanced personality. In the Islamic education system, the purpose of gaining knowledge is to create perfection in all aspects of human life. A person often needs to undergo spiritual and personal transformation to develop spiritually. Before proceeding with the discussion of various types of intelligence and educational curricula, it is important to clarify the problem of human nature in relation to learning and knowledge acquisition.

\section{Human nature}

Analysis of human nature was carried out by Professor A. R. Momin in his article "Homo Islamicus-Human Nature in Islamic Perspectives" published in the IOS Tower in 2009 (Momin, 2009). Momin stated that Islam offers a balanced and realistic view of human nature, as manifested by four approaches: glorifying perspective, duality and polarity of human nature, deterministic human nature, and the role of the social and educational environment in character. First is a perspective that glorifies human nature based on quotes from various sources. Quotations from the Qur'an show that humans were created using the best printing and have been given authority over all living things in the universe. Momin asserted that man was created as a self-conscious being by God and his creation was for a noble cause. At birth, all humans are innocent and free from sin or guilt. Down from Adam, the first human on Earth, everyone is equal before God. Scholars also point out that humans are considered as representatives of God in this world (Momin, 2009).

The second perspective concerns the form of duality or polarity in human nature. According to Momin (2009), the verses of the Qur'an state that man was created from clay, a low material (Al-Qur'an 23:12; 32: 7). Then, Allah "breathed His soul into man" to produce living things (Qur'an 15:29). Momin (2009) asserts that there are two conflicting aspects of human nature: it is sublime and like divine, on the one hand, and it is low and evil, on the other. Momin mentioned the story of Qabil and Habil in the 
Qur'an to show this dualism in human nature. Humans have a tendency to be impatient, greedy and ungrateful, and focus on their desires arouses their unjust behavior (AlQuran 70:19; 45:23 in Momin, 2009).

The third perspective refers to the demonstration of human nature in a deterministic way in Islam. It is clear from the Islamic belief that God bestows human selfawareness and the ability to think and make moral decisions, as well as the right to choose between the path of good and evil (Momin, 2009). The fourth perspective concerns the role played by the social and educational environment in developing human capabilities. Momin (2009) quoted the words of the Prophet Muhammad that humans were born in a natural state and followed the teachings and religion of their parents. The Prophet also said that people followed the path chosen by their friends and therefore warned them not to choose the wrong friends. Induction of Islam also suggests codes of conduct to develop human abilities and to limit the negative tendencies in their nature (Momin, 2009).

Experts have also considered the problem of human nature a lot. For example, Abu Hamid Al-Ghazali asserted that the initial knowledge contained in every human soul such as seeds on the ground, so it must be cultivated and developed to achieve visible and conscious forms (Hanani, 2014). In addition, Al-Ghazali believes in the high level of responsibility entrusted to parents in educating and developing their children, and the great potential of the family to direct the child's personal growth and progress.

(Fuadi, 2013) stated that the innate nature of a child implies the ability to take the path of good or evil. The way the child is nurtured and the inner family environment determines the direction it takes. To prove his opinion, refer to the words of the Prophet Muhammad about the primordial nature (fitra) that was just born at birth, with his parents forming the beliefs of what he would have. AlGhazali (1995) asserts that education given to a child by parents and teachers is responsible for the success and happiness of the child in the future. If parents and teachers provide children with the right direction of life, the child is likely to achieve happiness in this life and the hereafter. In the case of parental neglect and wrong education, the child cannot succeed in life. Al-Ghazali (1995) believes that the teachings of God are the main values for children's early education, to give them knowledge about true happiness and success needed for a life determined by God.

Another philosopher, Ibn Khaldun, in his historical work, The Muqaddimah, stated that human is inherently social, with good and evil inclinations in their nature (Momin, 2009). In Khaldun's perspective, humans are given the ability to think, regulate their relationships with the world, and with other humans, according to the laws and regulations that a person gains through personal experience, especially family and culture. Ibn Khaldun (1967) believed that humans had no knowledge at birth and were only "raw materials" at that time. They slowly begin to change into "form" because of the knowledge they have gained from time to time using their organs. He recognizes humans as basically stupid people, turning into complete humans only by the accumulation of knowledge (Alatas, 2013).

Shah Waliullah suggested that human beings are created as self-aware figures with the ability to reason allowing him to develop various values, ideals, and opportunities. In line with Waliullah's thinking, these characteristics are common to all humanity and are therefore universal (Cholik, 2015). The scholar stated that the attributes of good and evil were inherent in humans, creating a source of ongoing internal tension and anxiety. Factors such as reason, experience, revelation and learning produce impacts on various human actions. The complexity of human nature is also discussed by Jalaluddin Rumi, a thirteenth-century Sufi mystic, who claims that human spiritual experience gained through education can bring any individual beyond worldly concern and can help find meaning, values, and direction of life. He also showed in Fihi ma Fihi that human nature has two aspects, juggling between the angelic world and the human world (Momin, 2009).

On the contrary, Jamal-ad-Din Al-Afghani basically sees humans as evil, which shows that only through knowledge and education can a person move away from impulse impulses. Al-Afghani (in Bouzid, 1998, p. 45) writes that "man is very cruel and knows nothing", and from the beginning of that time was the cruelty that directed mankind to "the destruction of the social order". In the "Commentary on the Commentator", Al-Afghani writes that it is through education that people acquire their character and habits: "knowledge protects people from their inhuman nature" (Bouzid, 1998, p. 45).

In short, Muslim philosophers have different views about the inherent characteristics of human nature when talking about self-awareness, but all agree on the importance of education. The general description of their conceptions above allows us to establish a shared position that humans do not have any knowledge at birth. Knowledge comes from experiences in various social environments - parents, family, culture and school - that influence their life choices, in terms of good or bad. In addition, Ibn Khaldun (1967) focused on the role of God in the acquisition of individual knowledge. Therefore, the importance of knowledge and education for human development cannot be ignored. In line with this, the next section deals with Al-Ghazali's Theory of Knowledge, clarifying the various types of knowledge in the world, and how they can be obtained.

\section{Spiritual Intelligence and Intellectualism in Islamic Context}

In the Islamic context, education refers to a process that takes into account all persons, including spiritual, rational, and social aspects. Syed Muhammad Al-Naquib Al-Attas points out that the aim of an integrated approach to education in Islam is to create a "balanced growth of total personality ... through training the spirit, intelligence, rational human self, feelings and senses of the human body ... in such in such a way that faith is incorporated into his entire personality (Al-Attas, nd, p. 158) In the Islamic education system, the aim of gaining knowledge is to create perfection in all aspects of human life. According to Islamic 
theorists, the Prophet Muhammad is the greatest model of perfection and most valuable, and the goal of Islamic education is to motivate people to spend their lives in a manner similar to the Prophet's. According to Sayyed Hossein Nasr (1979, np), education provides happiness for humanity and "its main goal is permanent residence and all education shows eternal world ".

Al-Ghazali (1996) proposed five important elements that need to be incorporated into education, namely religion, soul, intelligence, resources, and family integrity. He supported the view that any material that drives these elements might be beneficial to society, while anything that impedes the fulfillment of these elements can be detrimental to society. Scholars recognize these concepts as universal and therefore function as a basic block for all societies. The curriculum objectives formulated by AlGhazali (in Alkanderi, 2001) concern the creation of individuals who are responsible for preparing them for life after death. Therefore, these important elements must be incorporated into the education system to assist the community in developing humanistic and educated citizens (Alkanderi, 2001).

The educational philosophy of Al-Ghazali (1988) is based on the assumption that it is important for humans to be taught the difference between things that are essential for survival in the world and things that drive a person to a higher level of spiritual development, with knowledge of things important for human life and evolution (Dakhil Allah, 1996). In line with these ideas, Al-Ghazali implicitly suggested a curriculum that combines the following components: spiritual love, the essence of worship, and appropriate social behavior. He urged parents not to approve of habits such as gluttony when instructing children to avoid overeating.

As a consequence of human social evolution, advances in science and technology have had an impact on the development of Islamic scholarship. Thus, Sayyid Qutb interpreted the text of the Qur'an by stating that, in some circumstances, scientific progress is considered a form of worship to God and an important purpose of human creation. He claims all Muslims are ordained to seek scientific knowledge; this idea was revolutionary for the time and contrasted with the traditional Islamic view of education (Murr, 2004). Similar to Qutb, Al-Afghani (1838 - 1897), an Islamic reformer who promoted scientific knowledge and fought against Islamic "static retardation" (Bouzid, 1998, p. 24), also emphasized the importance of modern science and technology, and applied it to the context own religion. The scholar believed that only the development of science and technology could eliminate the economic and cultural backwardness faced by Muslims in the 19th century. However, he pointed out that Islam consists of strong spiritual and moral values and stressed the importance of incorporating these values into scientific and technological strength to drive the development and growth of the Muslim community (Tariq, 2011).

These ideas have been embedded deeply in Islamic education and have strategic potential with strong potential for Saudi education because they place priority on the recognition and development of talents in science and technology, and care for the holistic education process that can advance people to heights that have never been achieved before from its growth.

The views of different Muslim scholars, especially AlGhazali, show that in the Islamic context, education refers to a process that takes into account the whole person, including the spiritual, rational, and social aspects. Therefore, Islamic education requires an integrated approach to teaching to develop a balanced human personality. In the Islamic education system, the purpose of gaining knowledge is to create perfection in all aspects of human life. Humans often need to undergo spiritual and personal transformation to develop themselves spiritually. For this purpose, the next section discusses aspects of spiritual development.

\section{E. The Dimensions of Emotional and Spiritual Intelligence in Islam}

In Islam, emotional and spiritual intelligence refers to human growth, self-control, self-purification, God's awareness, discipline, spiritual development, and close relationship with God. Fatimah Abdullah (2012) distinguishes the main dimensions of emotional and spiritual intelligence as follows:

1) Self or emotional control: Spiritual intelligence refers to the maturity of characters that depend on the capacity to control themselves. This ability can be developed through spiritual maturity and discipline that allows the faithful to delay the fulfillment of their needs immediately. To control emotions, special knowledge is needed about holding one's opponent's strength. (Ibn Miskawayh, 1968)

2) Taqwa and self-awareness: Self-awareness is created through "Taqwa", which is the basis of emotional and spiritual intelligence. Through it, one can carry out self-analysis and realize one's feelings as they develop; observe how thoughts, feelings and reactions are related; evaluating various alternatives; identify strengths and weaknesses, and evaluate yourself realistically and positively. (Al-Jawziyyah, 1972)

Those who have emotional and spiritual intelligence are in a constant positive state, which leads to greater satisfaction and well-being for humans when compared to those who experience feelings of disappointment, misery, and anger (Al-Balkhi, 1984).

F. Components of Spiritual Intelligence in Islam

Spirituality and human morality always have a strong relationship in the tradition of Islamic religious education. A review of various scientific works on spiritual intelligence in Islam enables the identification of the following components:

1) The search for unity behind visible diversity;

2) Obtain and analyze spiritual messages of phenomena and events;

3) Questioning and getting moral answers about the basic essence (Origin and Resurrection);

4) Recognizing the stability of essence and interpersonal relationships on the quality of human integrity; 
5) Recognizing the virtues of developing from mistakes into implementation of forgiveness in interpersonal associations;

6) Determine spiritual patterns and regulate behavior based on moral models;

7) Identifying the respect and value of someone to maintain and develop dignity;

8) Identifying the process of spiritual development and changing internal and external elements to optimize the growth process;

9) Recognize the meaning of life, death, and other life events, such as mental heaven and hell;

10) Realizing the existence of God in normal life;

11) Understand the innate art and beauty and get a sense of appreciation and gratitude;

12) Having talent, desire, and mysticism, where the source of knowledge is love, not conclusions and assumptions;

13) Having poetic talent who can understand the underlying meaning of a poem; and,

14) Gain a deep understanding of the Qur'an and the teachings of the prophets. (Bagheri, Zarea \& Esmaili, 2013, p. 3546)

Therefore, the spiritual aspect is important for educating in Islam, teaching children to distinguish right from wrong, and encouraging them to do good while prohibiting evil things. Spirituality provides a strong background for one's moral growth, which will be explained further in the next section.

$G$. Intellectual Intelligence in the Islamic Context

As expressed in the above section, intellect, in Arabic, is known as al-aql; the term unites intelligence and reason (Nasr, 1979). In contemporary Islamic scholarship, the words "intellect" and "intelligence" are used interchangeably despite differences between the terms. The general meaning of this word depends on the idea of human ability to gain knowledge and understand things because of God's gift Tuhan (Nasr, 1979).

The concept of aql gained considerable recognition and consideration among various Muslim scholars. Aql can also examine knowledge based on world observations and deductions through personal experience. Finally, this relates to individual behavior in relation to ownership of certain types of knowledge. Therefore, it is important to analyze and apply elements of a broader view of Islamic philosophers. As offered by Al-Ghazali, curriculum development for gifted students embodies spiritual and intellectual harmonization.

Referring to Aristotle's ideas about intellect as a composition of moral truth, Al-Farabi recognizes them as part of the human soul responsible for undergoing "moral experience". The latter concerns cases when someone uses intelligence to distinguish between good and bad, to decide which actions should be taken, and which should be avoided (Flynn, 1948).

Al-Ghazali (1997) also contributed to the formulation of the definition and description of intelligence in an Islamic perspective by defining four features: quality (wasf); its ability to reveal ultimate truth to people; its acquisition through spiritual and worldly experiences; and, giving people the ability to ascertain the results of their actions. The scientific ideas above have the same basis, in the sense that the terms "intellectual" and "intelligence" are not identical at all, even though the two are interdependent. A person's dependence on intelligence obtained through careful personal experience or mental administration, or even biologically inherited, does not guarantee beneficial results. Having sufficiently large intelligence does not mean that pure knowledge is sufficient. Therefore, it is very important to utilize intelligence and intelligence to get optimal results. Developing this point, the next section discusses the importance of spirituality and education, and how spiritually gifted individuals are endowed with gifts from Allah.

\section{CONCLUSION}

Spiritual, moral and emotional intelligence is generally understood in the same way in both the Western and Islamic scientific traditions. However, but again, it is important to remember that Islamic thought is far more strongly embedded in religious traditions and derives most of its spiritual guidance, moral and emotional education from its religious writings, not from the current body of scientific research.

This research has examined various educational concepts postulated by Islamic thinkers in relation to gifted education. Although this perspective is somewhat different, Islam places the same emphasis on the importance of increasing knowledge, intelligence and intelligence, spirituality, emotions and morality. From the arguments presented, researchers can formulate a framework aimed at improving the curriculum for gifted children's education. This research framework suggests various ways that talented individuals can be handled to maximize their potential and improve their ability to find a place in a contemporary environment. Researchers believe that a holistic approach that covers various aspects of human development, such as spiritual, emotional stability and morality, is needed to support gifted children.

\section{REFERENCES}

[1] Alatas, S. F. (2013). Ibn Khaldun. In Ibn Khaldun. https://doi.org/10.1093/acprof:oso/9780198090458.001.0001

[2] Barlow, D. (2006). Keeping Track: How Schools Structure Inequality (Second edition.). Education Digest.

[3] Barnes, J. (2014). The complete works of Aristotle. In The Complete Works of Aristotle.

[4] Borland, J. H. (2005). Gifted education without gifted children: The case for no conception of giftedness. In Conceptions of Giftedness: Second Edition. https://doi.org/10.1017/CBO9780511610455.002

[5] Carroll, J. B., \& Guilford, J. P. (1968). The Nature of Human Intelligence. American Educational Research Journal. https://doi.org/10.2307/1161820

[6] Cholik, A. A. (2015). Relasi Akal dan Hati menurut al-Ghazali. KALIMAH. https://doi.org/10.21111/klm.v13i2.290

[7] Cooper, J. M. (2012). Pursuits of wisdom: Six ways of life in ancient philosophy from Socrates to Plotinus. In Pursuits of Wisdom: Six Ways of Life in Ancient Philosophy from Socrates to Plotinus. https://doi.org/10.5465/amle.2013.0116

[8] Flynn, J. V. (1948). The Philosophy of Alfarabi and Its Influence on Medieval Thought. Thought. https://doi.org/10.5840/thought194823459

[9] Fuadi. (2013). PERAN AKAL MENURUT PANDANGAN ALGHAZAL. Jurnal Substantia.

[10] Gardner, H. (1995). Reflections on Multiple Intelligences: Myths 
and Messages. Phi Delta Kappan. https://doi.org/10.1002/ss.327

[11] Hanani, D. (2014). Pendidikan Karakter Anak Menurut Imam AlGazali. Jurnal Pembaharuan Pendidikan Islam (JPPI).

[12] Immordino-Yang, M. H., \& Damasio, A. (2007). We Feel, Therefore We Learn: The Relevance of Affective and Social Neuroscience to Education. Mind, Brain, and Education. https://doi.org/10.1111/j.1751-228x.2007.00004.x

[13] Momin, A. R. (2009). Homo Islamicus-Human Nature in Islamic Perspectives. The IOS MINARET, 4(13). Retrieved from https://www.iosminaret.org/vol-4/issue13/Human-Nature-inIslam.php

[14] Nasr, S. H. (1979). Intellect and Intuition: Their Relationship from the Islamic Perspective. Studies in Comparative Religion.

[15] Noddings, N. (1997). Dialouge between believers and unbelievers. Religious Education. https://doi.org/10.1080/0034408970920208

[16] Norsaleha Mohd. Salleh, \& Noor Hafizah Mohd. Haridi. (2016). Konsep Kecerdasan Emosi Dalam Islam. Seminar Antarabangsa
Akidah, Dakwah Dan Syariah 2016 (Irsyad 2016).

[17] Reynolds, F. C., \& Piirto, J. (2005). Depth psychology and giftedness: Bringing soul to the field of talent development and giftedness. Roeper

Review. https://doi.org/10.1080/02783190509554311

[18] Sapon-Shevin, M. (1995). Why Gifted Students Belong in Inclusive Schools. In Educational Leadership.

[19] Sternberg, R. J. (2000). IQ and Human Intelligence. The Journal of Nervous and Mental Disease. https://doi.org/10.1097/00005053-200008000-00015

[20] Taylor, R. C. (2005). al-Fârâbi and Avicenna: Two Recent Contributions - Al-Fârâbi, Founder of Islamic Neoplatonism: His Life, Works and Influence, by Majid Fakhry. Great Islamic Thinkers. Oxford: Oneworld, 2002. 168 pages, index, appendix and bibliography. US $\$ 23.95$ (Paper) . Middle East Studies Association https://doi.org/10.1017/s0026318400048124
Bulletin. 